\title{
Aging, Economic Insecurity, and Employment: Which Measures Would Encourage Older Workers to Stay Longer in the Labour Market?
}

\author{
DIANE-GABRIELLE TREMBLAY \\ Télé-université de l’Université du Québec à Montréal, Montréal, Québec, Canada \\ ÉMILIE GENIN ${ }^{1}$ \\ École de relations industrielles, Université de Montréal, Montréal, Québec, Canada
}

\begin{abstract}
In the present context of aging populations, the question of how to support older workers who want to stay in employment longer is of particular importance, especially from a social justice perspective with regards to income. The challenges faced by organizations and governments are unprecedented. Interesting conclusions can be drawn from our research with regard to these challenges. First of all, the perception of retirement appears more or less unchanged over the years and remains very positive. Consequently, one of the barriers to the employment of older workers may be the image of retirement itself, since it is still perceived as a gift or a right. Secondly, our results confirm that forcing people to stay longer in the labour market is a largely unpopular measure. Consequently, if public retirement plans offer limited income, governments and organizations should adopt a more voluntary approach to encourage older workers to stay in employment longer for a better income. Our results highlight the importance of the sector and type of job in the measures or incentives that could encourage older workers to stay in employment longer. Consequently, governments and organizations will probably have to adopt a contingent approach; i.e., all incentives do not necessarily fit all jobs or all sectors and social justice would require this be taken into account. We identified three sets of measures that could encourage older workers to stay in employment longer, and thus have access to better economic security: the reduction of working time, the flexibility of working time, and the individualization of retirement options and working time. The progressive reduction of their working time appears most interesting to our respondents. These measures appear to favour social justice in terms of income and right to employment at the end of active careers.
\end{abstract}

Correspondence Address: Diane-Gabrielle Tremblay, Télé-université, l’Université du Québec à Montréal, Montréal, QC H2X 3P2, Canada. Tel: +1 514 843-2015, Email: dgtrembl@teluq.uqam.ca

Émilie Genin, École de relations industrielles, Université de Montréal, Montréal, QC H3C 3J7, Canada. Tel: +1 514 343-6111, Email: emilie.genin@umontreal.ca 


\section{Introduction}

The aging of the baby-boom cohort, coupled with subsequent declines in fertility, is contributing to accelerated population aging. These combined effects lead to immediate and near-future concerns with older workers (Habtu, 2002; Hicks, 2003a, 2003b; Marshall \& Mueller, 2002) as well as with possible problems of economic insecurity and insufficient incomes at retirement, especially in the context of the financial crisis which hit the world in 2008. As well, in Europe, in the face of low employment rates and high levels of poverty in some groups of the various countries' aging populations, in addition to preoccupations with maintaining public health and social security budgets, the "Lisbon Agenda" has called for an increase in the employment rates of aging populations (Conseil d'Analyse Economique [CAE], 2005; Guillemard, 2007; Inspection générale des affaires sociales [IGAS], 2004).

With the aging of the population, our perception of retirement as an institution is being questioned. The institutionalization of retirement, coupled with a dynamic increase in life expectancy over the past century, forged a period of time between when a person stopped working and died, called "retirement" (Marshall \& Mueller, 2002). Retirement as a major social institution created a separate category in the overall age structure. Retirement is a socially constructed institution, meaning there is nothing biologically inevitable about a "normal" age for retirement and that the "normal" moment for this can vary from one country or social group to another (Bellemare, Poulin, \& Tremblay, 1998; Marshall \& Mueller, 2002).

A series of studies by the International Labour Office (ILO) has provided ample evidence of how older workers are often used as a balancing factor to regulate labour supply, moving them out of retirement in response to economic pressure. The use of downsizing strategies is also a factor which contributed to lowering the retirement age of Canadian men (Statistics Canada, 2007). However, "Employment is a powerful means of mitigating the effects of aging on social protection schemes" (International Labour Office [ILO], 2005, p. 13). While this has been recognized for some time (Commission Européenne, 1999; Supiot, 1999), the pressure seems to have increased over recent years (CAE, 2005; Guillemard, 2003; IGAS, 2004; Morrissette, Schellenberg, \& Silver, 2004; Morrissette \& Shang, 2004).

Also, in the context of the present crisis, where many retired persons have seen their savings drastically reduced, staying in employment or returning to it may be one of the only ways of reducing economic and income insecurity (Tremblay, 2008), at least in the countries where public pension benefits are rather low and where people's retirement income depends in part on financial markets. It must be noted that even before the crisis, many retirees were returning to employment, partly because of insufficient income at retirement, the percentage having been evaluated at about a third in Canada (Tremblay, Najem, \& Paquet, 2007), and possibly increasing in the context of the present financial crisis; others (17\%) also return because of interest in their work. However, it is not always possible or desirable to return to work full time, since some aging workers have had a difficult work life experience or difficult working conditions, which may impede their capacity to work, and especially to work full time (David, 2007).

These two elements, i.e., the obligation for many to stay in or return to employment rather than opt for retirement, and the desire for adaptation of working 
conditions at the end of their career, brought us to look into this issue and design a survey to determine which measures would encourage older workers to stay in employment in a way that is acceptable or even desirable for them, while contributing to macroeconomic objectives without forcing this group into unwanted working situations.

Several types of measures have been taken to improve employment rates, including the establishment of targets by the majority of western countries (ILO, 2005), but to date these targets in themselves have had no impact, in the absence of changes in work organization. One aim of these targets is to extend the working life of aging people. While this is important, a key challenge is to find the precise means which will make it possible to increase the employment and participation rates of all population groups (ILO, 2005). This is an important challenge, since it has been shown that it is extremely difficult to change the image of retirement as a "gift" or a "right," and that not all workers have a positive view of employment at the end of their career (Bellemare et al., 1998). Indeed, research has shown there is a diversity of situations at retirement age, the differences relating to gender, professional category, sector, etc. (Bellemare et al., 1998; Tremblay, 2007).

As Guillemard (2007) has shown, the proposition put forward in France of pushing back the age of retirement, with the 2003 Fillon laws, does not necessarily have an impact on prolongation of activity. Indeed, as much research shows (David, 2007), if working conditions and working hours are not satisfactory, it is difficult to keep workers longer and if their working conditions are difficult, many workers do not, understandably, wish to prolong their activity. Most analysts now conclude that to facilitate employment of those aged $55-64$, it is necessary to redesign work and working time (David, 2007; Schetagne, 2007; Turcotte \& Schellenberg, 2005). This is why we wanted to address the issue of working time from a lifelong perspective, since it appears that the ternary or tripartite model (schooling, work, retirement succession) is challenged (Guillemard, 2007) and that working times should be envisaged in a more flexible way.

Indeed, over time, the institutionalization of the life course has led to three defined phases in life: education, work, and finally, retirement as a period for rest and leisure (Marshall \& Mueller, 2002). However, this tripartite model was adapted to the life course of White men and a given situation in terms of health and economics. The traditional pattern of three successive parts of the life course is now being questioned in Canada as in many other countries, and it is apparently being redefined (Guillemard, 2003).

These changes are simultaneously happening in the social, economic, and psychological spheres. If we consider the wide range of varied education and work experiences over the life course and family transitions such as multiple periods of singlehood, marriage, and child-rearing, the permutations in which life course transitions may occur is increasingly complex. However, in many societies such as Canada, there is a culturally normative conception of the life course. A move towards lifelong education presents a great challenge for public policymakers (Marshall \& Mueller, 2002), and a move to a more active end of life also presents management and social challenges. Indeed, this tripartite model has been questioned, since the three activities that traditionally were found in succession over the life course are now overlapping in the real life courses of individuals. 
Amongst the issues to be addressed are the fact that women are still far more likely to have non-linear or non-traditional careers than men, with movements in and out of the labour market and more part-time or occasional work (Tremblay, 2004). The women with unstable work histories are often less economically secure in later life (Marshall \& Mueller, 2002); they are amongst the groups who might want to prolong their labour force activity, although this is not always easy, nor desired, in all professional categories and all economic sectors (Bellemare et al., 1998, Tremblay, 2009). In the context of the crisis, more and more male workers also need to prolong their activity in the face of economic hardships and diminishing returns in their savings and pension plans (Rodgers, 2008). Moreover, recent studies and indicators suggest that older workers may stay in employment longer. In 2006, Canada registered a record proportion of 60 - to 64-year-olds in the labour force (45\%). Furthermore, the average age of retirement remained steady at 61.5-still up from a low of 60.9 in 1998 (Marshall \& Ferrao, 2007). However, behind this increase are two different trends for men and women. The participation rate for older men went from a high of $76 \%$ in 1976 to a low of 58\% in 1995, rebounding by 2007 to $67 \%$. Women, on the other hand, have seen a constant increase, from 32\% to 53\% (Marshall \& Ferrao, 2007).

Retirement behaviour is thus related not just to the immediate circumstances prior to retirement itself, but to the broader context of the career and economic situation at the moment of retirement (David, 2007; Marshall \& Mueller, 2002). Amongst the various factors mentioned to explain retirement or early retirement in particular, we can mention reasons related to health and to personal and professional issues. It appears that the social context of the longest occupation held at mid-career influences timing of complete exit from the labour force (Marshall \& Mueller, 2002). It also seems that stress and psychological pressure have an impact (David, 2007), as well as health and financial issues (Feldman, 1994; Gratton \& Haug, 1983). It has also been noted that the professional and economic situation of the partner is an important variable (Szinovacz \& De Viney, 2000; Van Solinge \& Henkens, 2005).

In the context of all of these challenges related to economic insecurity over the life course, and especially at the end of the life course, this article will address the issue of the aspirations of aging workers with respect to the end of their active life. Before we present the methodology of the research referred to here, and the results, let us present a few elements on the participation rates in Canada and Quebec, in order to complete the introduction and contextualization of the issue and data.

\section{Participation and Aging}

Quebec is the Canadian province which presents the most challenges since it will age most quickly; however, the rest of Canada follows close behind and the Canadian government is also preoccupied with this issue. The working age group (15-64) will soon start shrinking in Quebec, while those 65 and over will increase their share and those aged 0-14 will decrease their share substantially.

The problem of the aging population is all the more significant in Quebec in comparison to Ontario and the US since the age group of 55-64 is much less active in Quebec in comparison to the US and even to Ontario, although it is more active than

Studies in Social Justice, Volume 3, Issue 2, 2009 
in many European countries (Tremblay et al., 2007). Even if there has been an increase in the activity rate of these groups, it is still well below that of Canada and the US. The aging of the population is somewhat more accelerated in Quebec because it receives less immigration than the two other zones and immigrant families generally have more children.

In any case, given the present economic context, the realities of aging populations and the stress on public budgets in many countries, most countries are worried and searching for ways to encourage higher employment participation rates. This is also a worry for pensioners and recent retirees in many countries as well, especially with the crisis which has increased economic insecurity for many.

A study from Statistics Canada (2007) shows that the majority of the youngest pensioners continue to do some work for pay, but the attachment to the labour market loosens with age. The study found that at least half of people in their 50s who recently retired had at least some employment income the year after they began receiving their pension. However, if this threshold of employment income were raised to a mere $\$ 5,000$, the proportion would fall to less than one-third. The study found a sizeable gap between rates of post-pension employment for men and women. In 2004, one in three young male pensioners earned at least \$5,000 from employment the year after retirement; only one-quarter of their female counterparts did so.

Other studies have shown that women still contribute more time to housework and the care of the elderly, which may account for lower re-employment rates. Women earned less than men in both pensioned and non-pensioned groups (Statistics Canada, 2007). Data definitely showed a recovery in "re-employment" among early pensioners since the mid-1990s (Marshall \& Ferrao, 2007). During the 2000s, the rates have remained essentially flat, but it is expected they will increase with the present economic hardships, as many need to work to maintain a decent level of income. (Baril, 2004; Rodgers, 2008). Also, the loss of potential labour supply is highlighted by a significant gap in labour market attachment between pensioners and non-pensioners. This gap is clear at the age of 50, and widens for older age groups (Statistics Canada, 2007).

Consequently, the aging workforce has thus become a serious concern for many industrialized countries for about a decade and the challenge might be all the more important in the coming years, not only from an economic and budgetary point of view (need for higher employment rates in order to support the costs of an aging population) but also for the individual's economic security (CAE, 2005; Morrissette et al., 2004). Indeed, not only the massive retirement of the baby-boomer generation and the constant drop of birth rates are expected to provoke workforce shortage and the loss of invaluable knowledge for organizations, but the 2008 financial and economic crisis may reduce many retirees' income (Baril, 2004; Rodgers, 2008). For example, the market value of assets held in employer-sponsored pension funds fell by $8.7 \%$ during the third quarter of 2008, the largest quarterly decline in a decade (Statistics Canada, 2009).

In our study, in trying to determine avenues which are acceptable to aging workers and not only to governments and firms, we examine the image of retirement among a sample of retired and older workers. Since the needs and aspirations of older workers may in many ways differ from those of other workers, we also analyze measures that could possibly encourage them to stay in employment longer, since this appears to be one of the very few avenues possible, aside from increasing retirement pensions or 
imposing later retirement or other compulsory solutions, both of which appear difficult to realize in the present context (David, 2007; Morrissette et al, 2004). The increase in pension benefits is proposed by some, but in the absence of increased employment participation and fiscal revenues for the state, this does not appear feasible.

\section{Methodology}

We will present here the results of a vast survey carried out in collaboration with the Réseau Fadoq (previously Fédération de l'âge d'or du Québec, an association which represents the 50 and over, including some working people and other more elderly). This population was of interest because the members of this association, and thus all our respondents are either "older workers" or retired. The data were collected via the Internet during the spring of 2007. An e-mail was sent to the members of the association. It contained a hypertext link giving the members access to an online questionnaire. $^{2}$

We obtained 276 usable questionnaires; $54 \%$ of our respondents were women while $46 \%$ were men. This sample is not large enough to be considered as representative of the Canadian population; that is the reason that this study should be considered as exploratory. Nevertheless our results give interesting perspectives for further development.

Two-thirds of our respondents are between 55 and 64 years old, 15\% are under 55 years old and $17 \%$ are 65 years old or over. Nearly half of our respondents are currently retired, $25 \%$ are in employment without having ever been retired, and nearly one-third of our respondents returned to the labour market after their retirement (which is the percentage found in a representative survey for Canada) (Tremblay et al., 2007). Some $60 \%$ of them live with a spouse or partner which, as we saw earlier, can influence the end of career aspirations (Van Solinge \& Henkens, 2005).

The questionnaire we designed first asked general socio-demographic questions (age, gender, sector of activity, etc.) and information on their family situation (i.e., the day-to-day situation). The questionnaire then assessed the motivations for retirement and the measures that could encourage older workers to stay in employment longer. In order to do so, the respondents were invited to evaluate the importance of different motivations on a Likert's scale of five points $(1=$ very important; 5 = not important). The list of motivations for retirement integrates the results of different studies (David, 2007; Guillemard, 2007; Schetagne, 2007; Tremblay et al., 2007).

The respondents were also asked to express their agreement or their disagreement of a list of measures that could lead older workers to stay in employment longer. Every item was assessed on a Likert's scale in 5 points (very interesting $=1$; not interesting at all $=5$ ). The list of measures comes from different governmental reports (Quebec, 2003), proposals from the different aging workers' associations (FADOQ, 2007), as well as previous studies (David, 2007; Tremblay et al., 2007). The respondents were also asked to answer questions on the ideal age for retirement

Studies in Social Justice, Volume 3, Issue 2, 2009 
and on measures taken in other countries, such as raising the legal age of retirement from 65 to 67 years.

\section{Results}

\section{Ideal Age for Retirement}

First of all, we note a very positive perception of retirement among all our respondents, something which had been observed in other research, but of a more qualitative nature, some ten years ago (Bellemare et al., 1998). Indeed, it seems that ten years later, retirement is still perceived very positively and even as almost "the best time of life" by a large majority. In addition, we also note an important preoccupation with health. Consequently, retirement can be the best time of life inasmuch as one enjoys good health! Moreover, amongst our respondents still in the labour market, $40 \%$ plan to retire before 55 years of age. ${ }^{3}$ This percentage may appear very high but almost one quarter of them plans to retire between 65 and 69 years old.

Table 1. Perceptions of Later Retirement

Question: Some countries, such as Germany and the United States, decided to raise the legal age of retirement from 65 to 67 years to compensate for the aging population. This change aimed at encouraging people to stay in employment longer. Do you agree with this measure?

\begin{tabular}{ll}
\hline Yes, I totally agree & $13 \%$ \\
Yes, I agree & $17 \%$ \\
I don't know & $6 \%$ \\
No, I disagree & $38 \%$ \\
No, I totally disagree & $26 \%$ \\
\hline
\end{tabular}

According to our respondents (already retired or still in the labour market), the ideal age for retirement is around 60 years old, but answers are very heterogeneous with important standard deviation. Conversely, they consider on average that one is able to work until 70 years old, but answers are still very diverse. More than $60 \%$ of our respondents think it is absolutely possible to complete a work of quality after 65 years old. On the other hand, only $30 \%$ of them agree with the idea of raising the legal age of retirement from 65 to 67 years old; while $64 \%$ of them indicate their disagreement (sum of disagree and totally disagree) with this proposal. Table 1 gives the results of the question asked in relation to this.

Therefore, our results underline the massive refusal of our respondents to impose on all retirement at the age of 67. This is clearly an indication that forcing later retirement is quite unpopular (as was seen in France as cited in Guillemard, 2007), and therefore puts forward the question of measures which might make staying in the labour market of greater interest. 
Table 2. Preferred Measures for Remaining in Employment Longer

Question: If the following measures are (or were) offered by your employer, which ones do you think you will use (or did use) at the end of your career?

\begin{tabular}{ll}
\hline Progressive retirement & $16.9 \%$ \\
Flexitime & $11.8 \%$ \\
\hline Retirement and part-time job in the same organization & $6.6 \%$ \\
Reduced week to 4 days (paid 4 days) & $9.3 \%$ \\
Retirement and part-time job in the same organization & $6.6 \%$ \\
Longer annual holidays & $6.6 \%$ \\
Additional leaves & $6.2 \%$ \\
Voluntary reduced working time & $5.1 \%$ \\
Compressed week (5 days' work done in 4 days and paid the total of & \\
the normal hours) & $4.8 \%$ \\
Shorter working days & $3.7 \%$ \\
Possibility to telework some days a week & $2.6 \%$ \\
Voluntary shared job (two employees working half-time) & $1.8 \%$ \\
Possibility to telework full-time & $1.1 \%$ \\
\hline
\end{tabular}

Question: If the following measures are not (or were not) offered by your employer, which ones would you like to use (or would you have liked to use) at the end of your career?

\begin{tabular}{ll}
\hline Progressive retirement & $13.0 \%$ \\
Retirement and part-time job in the same organization & $11.9 \%$ \\
Longer annual holidays & $10.2 \%$ \\
Possibility to telework some days a week & $8.9 \%$ \\
Voluntary shared job (two employees working half time) & $8.7 \%$ \\
Flexitime & $8.2 \%$ \\
Voluntary reduced working time & $8.0 \%$ \\
Shorter working days & $6.9 \%$ \\
Additional leaves & $6.1 \%$ \\
Reduced week in 4 days (paid 4 days) & $5.6 \%$ \\
Constricted week in 4 days (paid the total of the normal hours) & $4.1 \%$ \\
Possibility to telework full-time & $3.7 \%$ \\
\hline
\end{tabular}


Also, our respondents appear to be interested in measures allowing a progressive passage to retirement and/or maintaining a part-time job as measures to encourage them to stay in employment longer. Other measures include: retirement combined with part-time work, flexitime, longer annual holidays, and additional leaves (see Table 2). Thus, we note a demand for reduced and adapted working time in preparation for retirement, as well as more flexible forms of retirement.

Table 3. Preferred Form of Retirement

Question: What type of retirement did you take (or want to take)?

\begin{tabular}{ll}
\hline Progressive retirement & $21.1 \%$ \\
Full retirement & $30.4 \%$ \\
Early retirement & $10.0 \%$ \\
Retirement and another full-time job & $1.4 \%$ \\
Retirement and another part-time job & $17.5 \%$ \\
Retirement and self-employment & $15.4 \%$ \\
Other & $4.3 \%$ \\
\hline
\end{tabular}

As Table 3 shows, a third of our respondents took, or would like to take, a definitive retirement, $21 \%$ a progressive retirement and $17.5 \%$ would like to return, or have returned, to employment in another part-time job after their retirement. Consequently, it is interesting to note that nearly half of our respondents continue, or think they will continue to work after their retirement. This result may support the need for public policies aimed at maintaining more of the aging workers in the labour market, but also may translate feelings of economic insecurity on the part of these individuals.

As regards the retired and pre-retired respondents, the main reasons for retirement or pre-retirement are: the desire for more flexibility with one's time, the possibility to accomplish new projects and the possibility to have more time. The desire to have more time is therefore a very important variable for respondents who decide to retire, and it has also a significant impact on the questions concerning the measures which would encourage older workers to stay in employment longer. Appendix A presents the principal reasons that made our respondents decide to retire or take early retirement.

\section{Measures or Incentives to Stay in Employment Longer}

Among the measures which could, according to our respondents, encourage them to stay in employment longer, the most popular are: progressive retirement, flexible working hours, longer holidays and keeping a part-time job in the same organization at the same time as retirement (see Appendix B). No statistically significant differences were found between men and women, except one. More women than 
men are interested in shorter working days (61\% of them find this measure a very interesting or rather interesting measure, as compared to $35 \%$ of men).

In the health sector, we note a much more marked interest for additional days off and longer annual holidays than in other sectors. This may reflect the situation of workforce shortage in this sector, in which obligatory overtime is a widespread practice. Consequently, it seems that aging workers in this sector aspire, more than in other professional categories, to more time off, or to more time to "breathe" (see Appendix C and Tremblay \& Larivière, 2009).

In addition, the demand for telework is stronger in the education/research and public sectors, perhaps because this type of job is particularly suitable for telework. Finally, it is in the public sector that we find the highest rate of respondents declaring that no measure would persuade them to stay in employment longer. This may be due to the relative stability of the pension benefits in the public sector and the fact that they are often better than those found in the private sector.

According to our respondents the main factors that could favour the participation of those 50-years-old and over in the labour market are: progressive retirement, more flexible working conditions, and longer holidays (see Appendix B). It is interesting to note that these factors are not directly linked to governmental measures but are more linked to the goodwill of employers.

As in the case of retired persons, respondents still in employment express a demand for more flexibility at the end of their career. Moreover, a third of them plan to have a paid occupation after they retire, but only part-time (see Table 3). About $75 \%$ of our respondents still in employment would like to have the possibility to work at home occasionally. This result is interesting because telework is sometimes considered as a possible solution to work-family conflict, and this especially in the presence of young children. However, our result shows that telework can also interest older workers, or even encourage them to stay in employment longer.

Thanks to factorial analysis (see results in Appendix D), we found three factors to sum up the measures which, according to our respondents, could encourage older workers to stay in employment longer. Consequently, the incentives government and/or employers can use to persuade older workers to stay in employment longer are of three types, all related to flexibility of working time, as well as of retirement:

The reduction of working time: The first set of measures focuses on the reduction of working time, through more holidays and leaves. It includes: reduced week in four days (four days paid), work week compressed in four days (paid the total of the normal hours), shorter working days, additional leaves, longer annual holidays. These measures seem particularly attractive for older workers that experience pressure and strain at work, for example nurses and others in the health sector. Other Canadian data from the Workplace Employee Survey support this interest for reduction in working time for aging workers (Tremblay \& Najem, 2009).

The flexibility of working time: The second set of measures concerns the flexibility of working time, including the possibility of telework. It includes the following measures: possibility to telework some days a week, possibility to telework full time, and flexitime. These measures could persuade older workers to stay in employment through better working conditions, with more control in the way they can organize

Studies in Social Justice, Volume 3, Issue 2, 2009 
their time. This type of measure might not be available to all workers, since many professions require the physical presence of workers, in the construction or in the health sectors, for example. Nevertheless, this may be an interesting avenue for sectors in which tasks can be easily relocated to home (e.g. administrative workers).

The individualization of working time and retirement options: Finally, the last set of measures deals with the individualization of working time, which means adapting retirement and working time to the specific needs of each worker at different stages of his/her life. It includes individual arrangements such as flexible working hours at the end of career, voluntary reduced working time, voluntary shared jobs (two employees working half time), progressive retirement, retirement and a part-time job in the same organization, retirement and activity or job in another organization.

This avenue has been studied with regard to work-life balance, but research is still needed with regard to adapting work to older workers. This is certainly a promising approach but it presents huge challenges in practice for employers. Indeed, such an approach would demand a deep reflection on work organization and on task coordination. These challenges also interfere with other challenges related to knowledge management, i.e., how to ensure the transmission of knowledge from one generation of workers to another in such a context. This is surely not impossible, but requires some thinking and reorganization on the part of employers, although some consider that employers are often the source of lack of knowledge transfer (Flamant, 2005).

\section{Discussion/Conclusion}

In the context of aging populations, the question of how to support older workers who want to stay in employment longer is of particular importance, especially from a social justice point of view. The challenges faced by organizations and governments are unprecedented and need original responses. The demographic evolutions most industrialized countries are facing question the traditional tripartite model of education-work-retirement, according to which these three phases are found in a succession, with little or no overlap. Indeed, continuing education is more and more needed to maintain the competences of workers throughout their work life (Tremblay, 2008). Moreover, retirement can represent a period of time nearly equal to work life. The cost of this "expanded" retirement is judged unacceptable by many governments, leading to the question of how to encourage older workers who want to stay in employment longer. Interesting conclusions can be drawn from our research with regard to these challenges.

First of all, the perception of retirement appears more or less unchanged over the years. Its perception is still very positive. Consequently, one of the barriers to the employment of older workers is, perhaps, the image of retirement itself, since it is still perceived as a gift or a right. Furthermore, the perception of retirement contrasts with the perception of age. Indeed, a large majority of respondents do believe one can carry out work of quality after 65 years old, but nevertheless, many appear to want to retire. This result questions work in itself. Why do older workers want to stop working? Is work too hard? Too boring? Too exhausting? Unsatisfactory? If 
they want to retain older workers, organizations and managers will have to adapt work to their specific needs.

Secondly, our results confirm that forcing people to stay longer in the labour market is a largely unpopular measure. Consequently, governments and organizations should probably adopt a more voluntary approach; hence the importance of the evaluation of the different options to encourage older workers to stay in employment longer, since they vary from one professional category and sector to another.

Our results highlight the importance of the sector in the measures or incentives that could encourage older workers to stay in employment longer. The reasons that people would stay in employment longer depend on the type of job. Consequently, governments and organizations will probably have to adopt a contingent approach; i.e., all incentives do not necessarily fit all jobs or all sectors.

We identified three sets of measures that could encourage older workers to stay in employment longer (the reduction of working time; the flexibility of working time and the individualization of retirement options and working time). The relevance of these incentives seems to depend on the job and sector characteristics. As a consequence, more research is needed to determine more in depth which kind of measures could produce positive effects in various sectors. This conclusion also leads us to underline the role of the work environment, level of revenue, and income security in the decision to retire.

Among the measures that could support older workers who want to stay in employment longer, we identified the progressive reduction of their working time. Such an approach represents an important breach in the traditional tripartite model. Indeed, it would inaugurate a new period of time between work life and total retirement. Organizations and government should then develop new systems (in terms of social security, laws, etc.) to institutionalize this period of time so that older workers can draw advantages from it without losing the benefits of their retirement, thus ensuring social justice between the various categories of workers.

Solutions for governments and organizations are neither simple nor unilateral. In order to produce positive effects, the measures taken should be integrated with a deeper reflection on work organization and retirement options.

\section{Notes}

1 Diane-Gabrielle Tremblay is Canada Research Chair on the socio-organizational challenges of the Knowledge Economy and professor at the Télé-université de l’Université du Québec à Montréal) and Emilie Genin was post-doctoral student at the Chair during this research and is now professor at Université de Montréal. The authors wish to mention their appreciation for the comments provided by their three anonymous reviewers.

2 Since the Internet is not necessarily the best way to reach aging workers or retirees, we also distributed questionnaires at an activity of the FADOQ, and received five questionnaires here. Unfortunately, the participants in this activity were mainly the most elderly and they were for the most part quite far from employment preoccupations, having retired many years ago or not even having ever worked in the case of some elderly women. So in the end, the Internet appeared to be a better way to obtain answers from aging workers who were about to leave the labour market or had just done so.

3 At least this was the case in 2007, when the survey was done; the economic crisis may have some effect, possibly increasing the level of those who might want to stay on, but 
simultaneously pushing more into unemployment and eventually retirement because of the lack of job possibilities.

\section{References}

Baril, G. (2004). La hausse de l'activité chez les 55-64 ans : phénomène économique ou démographique? Downloaded from: http://www.cetech.gouv.qc.ca/publications/index.asp?categorie=0700102\&type=\&page=2

Bellemare, D., L. Poulin, S., \& Tremblay, D-G. (1998). Le paradoxe de l'âgisme dans une société vieillissante; enjeux et défis de gestion. Montréal: Ed. St-Martin.

Commission Européenne. (1999). The European labour market in light of demographic change. Luxembourg: Office des Publications des Communautés Européennes.

Conseil d'Analyse Economique (CAE). (2005). Les seniors et l'emploi en France. Paris: La documentation Française.

David, H. (2007). Quand la gestion des âges est inapplicable : la précarité d'emploi d'infirmières en soutien à domicile. In D.-G. Tremblay (Ed), Vers un nouveau management des âges et des temps sociaux. Québec: Presses de l'université du Québec.

FADOQ. (2007). Pour favoriser l'adaptation du marché du travail aux changements démographiques. Downloaded from: www.fadoq.ca

Feldman, D. C. (1994). The decision to retire early: A review and conceptualization. The Academy of Management, 19(2), 285-311.

Flamant, N. (2005). Conflit de générations ou conflit d'organisation? Un train peut en cacher un autre..., Sociologie du travail, 47(2), 223-244.

Gratton, B., \& Haug M. R. (1983). Decision and adaptation. Research on Aging, 5, 59-76.

Guillemard, A.-M. (2007). Vers un nouveau management des âges et des temps sociaux en réponse au vieillissement de la population: une perspective internationale. In D.-G. Tremblay (Ed.), Vers un nouveau management des âges et des temps sociaux (pp. 15-30). Québec: Presses de l'université du Québec.

Guillemard, A.-M. (2003). L’Âge de l'emploi. Les sociétés à l'épreuve du vieillissement. Paris: Armand Colin.

Hhabtu, R. (2002). Men 55 and older: Work or retire? Perspectives on Labour and Income, 15(1), 47-54.

Hicks, P. (2003a). New policy research on population aging and life-course flexibility. Policy Research Initiative, 6(2), 3-6.

Hicks, P. (2003b). The policy implications of aging: A transformation of national and international thinking. Policy Research Initiative, 6(2), 12-16.

Inspection générale des affaires sociales (IGAS). (2004) Gestion des âges et politiques de l'emploi : Rapport annuel de l'Inspection générale des affaires sociales. Paris: La documentation française.

International Labour Office (ILO). (2005) Managing transitions: Governance for decent work - Seventh European Regional Meeting: report of the Director General. Geneva: ILO

Marshall, V. W., \& Mueller, M. M. (2002). Rethinking social policy for an aging workforce and society: Insights from the life course perspective. Ottawa: Canadian Policy Research Networks.

Marshall, K., \& Ferrao, V. (2007). Participation of older workers. Perspectives on Labour and Income, 8(8), 5-11.

Morrissette, R., Schellenberg, G., \& Silver C. (2004). Inciter les travailleurs âgés à rester au poste. L'emploi et le revenu en perspective, 5(10), 16-22.

Morrissette, R., \& Shang, Z. (2004). Retirement plan awareness. Perspectives on Labour and Income, 6(1), 37-44.

Quebec. Ministère de l'emploi. (2003) Stratégie d'intervention à l'intention des travailleuses et des travailleurs de 45 ans et plus. Quebec: Ministère de l'emploi.

Rodgers, C. (2008, December 1). Le retour des têtes blanches. La Presse. Retrieved from: http://lapresseaffaires.cyberpresse.ca/

Schetagne, S. (2007). Le syndrome du compte à rebours. In Tremblay, D.-G. (Ed.), Vers un nouveau management des âges et des temps sociaux (pp. 92-126). Québec: Presses de l'université du Québec.

Statistics Canada. (2007, February 21). Study: Young pensioners. The Daily. Ottawa, ON: Statistics Canada. Retrieved from: http://www.statcan.gc.ca/daily-quotidien/070221/dq070221d-eng.htm 


\section{Diane-Gabrielle Tremblay and Émilie Genin}

Statistics Canada. (2009, March 12). Employer pension plans (trusteed pension funds). The Daily. Ottawa, ON: Statistics Canada. Retrieved from: http://www.statcan.gc.ca/daily-quotidien/090312/dq090312deng.htm

Szinovacz, M. E., \& De Viney, S. (2000). Marital characteristics and retirement decisions. Research on Aging, 22, 470-498.

Supiot, A. (Ed.). (1999). Au-delà de l'emploi : Transformations du travail et devenir du droit du travail en Europe (Rapport pour la Commission des Communautés Européennes). Paris: Flammarion.

Tremblay, D.-G. (2008). From casual work to economic security: The paradoxical case of selfemployment. Social Indicators Research. 88, 115-130.

Tremblay, D.-G. (Ed.). (2007). Vers un nouveau management des âges et des temps sociaux. Québec: Presses de l'université du Québec.

Tremblay, D.-G. (2004). Économie du travail; Les réalités et les approches théoriques (rev. ed.). Montréal: Editions Saint-Martin et Descarries éditeur.

Tremblay, D.-G (2009). D’une culture de retraite vers de nouvelles fins de carrière ? Québec : Téléuniversité, Presses de l’université du Québec.

Tremblay, D.-G., Najem, E., \& Paquet, E. (2007). Travail et vieillissement : Vers une nouvelle articulation des temps sociaux sur l'ensemble du parcours de vie? In D.-G. Tremblay (Ed.), Vers un nouveau management des âges et des temps sociaux (pp. 65-82). Québec : Presses de l’université du Québec.

Tremblay, D-G., \& Larivière, M. (2009). La conciliation emploi-famille dans le secteur de la santé au Québec : le soutien organisationnel fait-il défaut aux infirmières? In Genre et diversité en gestion. Paris: AGRH. pp. 101-118.

Tremblay, D.-G. \& Najem, E. (2009). Work, age and working time preferences: Towards a new articulation of social times in a context of economic crisis? The International Journal for Responsible Employment Practices and Principles. 1(1) 53-71.

Turcotte, M., \& Schellenberg, G (2005). Job strain and retirement, Perspectives on Labour and Income, 17(3), 35-39.

Van Solinge, H., \& Henkens, K. (2005). Couples' adjustment to retirement: A multi-actor panel study. Journal of Gerontology: Social Sciences, 60B, S11-S20. 


\section{Appendix A: Reasons Contributing to Decision to Retire or to Take Early Retirement}

Question: Did the following reasons contribute to your decision to retire or to take early retirement?

\begin{tabular}{|c|c|c|c|c|c|}
\hline & $\begin{array}{c}\text { Very } \\
\text { important }\end{array}$ & Important & Neutral & $\begin{array}{l}\text { Not really } \\
\text { important }\end{array}$ & $\begin{array}{c}\text { Not } \\
\text { important } \\
\text { at all }\end{array}$ \\
\hline $\begin{array}{l}\text { Because my work was too } \\
\text { hard }\end{array}$ & $13.42 \%$ & $14.09 \%$ & $4.03 \%$ & $25.50 \%$ & $42.95 \%$ \\
\hline $\begin{array}{l}\text { Because my work was too } \\
\text { tiring }\end{array}$ & $12.84 \%$ & $13.51 \%$ & $12.84 \%$ & $22.30 \%$ & $38.51 \%$ \\
\hline $\begin{array}{l}\text { I was unsatisfied with the } \\
\text { nature of my job }\end{array}$ & $16.78 \%$ & $10.07 \%$ & $14.09 \%$ & $12.75 \%$ & $46.31 \%$ \\
\hline I was unemployed & $1.46 \%$ & $2.19 \%$ & $0.73 \%$ & $5.11 \%$ & $90.51 \%$ \\
\hline $\begin{array}{l}\text { I could not find a job } \\
\text { meeting my expectations }\end{array}$ & $3.65 \%$ & $2.92 \%$ & $2.19 \%$ & $7.30 \%$ & $83.94 \%$ \\
\hline $\begin{array}{l}\text { I was unsatisfied with the } \\
\text { relationships with my boss } \\
\text { and colleagues }\end{array}$ & $10.56 \%$ & $13.38 \%$ & $15.49 \%$ & $8.45 \%$ & $52.11 \%$ \\
\hline I wanted no more bosses & $12.59 \%$ & $3.50 \%$ & $10.49 \%$ & $13.29 \%$ & $60.14 \%$ \\
\hline $\begin{array}{l}\text { I wanted more } \\
\text { independence and freedom }\end{array}$ & $17.24 \%$ & $13.10 \%$ & $11.72 \%$ & $15.17 \%$ & $42.76 \%$ \\
\hline $\begin{array}{l}\text { Because my job was } \\
\text { precarious }\end{array}$ & $5.67 \%$ & $2.84 \%$ & $4.96 \%$ & $7.80 \%$ & $78.72 \%$ \\
\hline $\begin{array}{l}\text { I wanted more flexibility to } \\
\text { organize my time }\end{array}$ & $20.42 \%$ & $19.01 \%$ & $15.49 \%$ & $9.86 \%$ & $35.21 \%$ \\
\hline $\begin{array}{l}\text { I wanted to spend more } \\
\text { time with spouse and/or } \\
\text { family }\end{array}$ & $8.33 \%$ & $16.67 \%$ & $15.97 \%$ & $11.11 \%$ & $47.92 \%$ \\
\hline $\begin{array}{l}\text { Because I couldn't balance } \\
\text { my work with my family }\end{array}$ & - & $7.04 \%$ & $5.63 \%$ & $12.68 \%$ & $74.65 \%$ \\
\hline $\begin{array}{l}\text { Because I was caring for an } \\
\text { elderly parent }\end{array}$ & $1.42 \%$ & $1.42 \%$ & $5.67 \%$ & $5.67 \%$ & $85.82 \%$ \\
\hline $\begin{array}{l}\text { Because my spouse or } \\
\text { partner was retired }\end{array}$ & $3.57 \%$ & $4.29 \%$ & $4.29 \%$ & $10.00 \%$ & $77.86 \%$ \\
\hline $\begin{array}{l}\text { Because I had enough } \\
\text { money to retire }\end{array}$ & $16.08 \%$ & $20.28 \%$ & $20.98 \%$ & $9.79 \%$ & $32.87 \%$ \\
\hline $\begin{array}{l}\text { Because I wanted to do } \\
\text { more volunteering }\end{array}$ & $3.55 \%$ & $7.09 \%$ & $14.18 \%$ & $17.02 \%$ & $58.16 \%$ \\
\hline To carry out new projects & $24.14 \%$ & $30.34 \%$ & $17.24 \%$ & $6.90 \%$ & $21.38 \%$ \\
\hline $\begin{array}{l}\text { To have more time for } \\
\text { myself }\end{array}$ & $31.08 \%$ & $34.46 \%$ & $15.54 \%$ & $4.73 \%$ & $14.19 \%$ \\
\hline $\begin{array}{l}\text { Because my health was too } \\
\text { bad to continue to work }\end{array}$ & $13.89 \%$ & $4.86 \%$ & $13.19 \%$ & $7.64 \%$ & $60.42 \%$ \\
\hline
\end{tabular}




\section{Appendix B: Measures or Incentives to Stay in Employment Longer}

Question: If all of the following measures were offered, which ones would encourage you (or have encouraged you) to stay in employment longer?

\begin{tabular}{|c|c|c|c|c|c|}
\hline & $\begin{array}{l}\text { Very } \\
\text { interesting }\end{array}$ & interesting & Neutral & $\begin{array}{l}\text { Not really } \\
\text { interesting }\end{array}$ & $\begin{array}{c}\text { Not } \\
\text { interesting } \\
\text { at all } \\
\end{array}$ \\
\hline Progressive retirement & $50.49 \%$ & $25.73 \%$ & $11.65 \%$ & $4.37 \%$ & $7.77 \%$ \\
\hline $\begin{array}{l}\text { Flexible working hours at the } \\
\text { end of career }\end{array}$ & $46.58 \%$ & $30.59 \%$ & $10.50 \%$ & $3.65 \%$ & $8.68 \%$ \\
\hline Flexitime & $43.96 \%$ & $22.71 \%$ & $13.53 \%$ & $7.25 \%$ & $12.56 \%$ \\
\hline Longer annual holiday & $42.58 \%$ & $28.23 \%$ & $12.44 \%$ & $5.74 \%$ & $11.00 \%$ \\
\hline $\begin{array}{l}\text { Retirement and part-time job in } \\
\text { the same organization }\end{array}$ & $37.62 \%$ & $33.33 \%$ & $12.38 \%$ & $5.24 \%$ & $11.43 \%$ \\
\hline Additional leaves & $30.50 \%$ & $32.50 \%$ & $17.50 \%$ & $6.50 \%$ & $13.00 \%$ \\
\hline $\begin{array}{l}\text { Possibility to telework some } \\
\text { days a week }\end{array}$ & $28.43 \%$ & $21.57 \%$ & $18.14 \%$ & $7.84 \%$ & $24.02 \%$ \\
\hline $\begin{array}{l}\text { Voluntary reduced working } \\
\text { time }\end{array}$ & $28.14 \%$ & $26.13 \%$ & $24.12 \%$ & $7.04 \%$ & $14.57 \%$ \\
\hline $\begin{array}{l}\text { Reduced week in } 4 \text { days (paid } \\
4 \text { days) }\end{array}$ & $24.64 \%$ & $25.12 \%$ & $22.22 \%$ & $11.11 \%$ & $16.91 \%$ \\
\hline $\begin{array}{l}\text { Retirement and activity or job } \\
\text { in another organization }\end{array}$ & $22.92 \%$ & $22.40 \%$ & $27.60 \%$ & $9.38 \%$ & $17.71 \%$ \\
\hline Shorter working days & $22.17 \%$ & $25.12 \%$ & $22.17 \%$ & $8.37 \%$ & $22.17 \%$ \\
\hline $\begin{array}{l}\text { Constricted week in } 4 \text { days } \\
\text { (paid the total of the normal } \\
\text { hours) }\end{array}$ & $21.29 \%$ & $12.38 \%$ & $14.85 \%$ & $20.79 \%$ & $30.69 \%$ \\
\hline $\begin{array}{l}\text { Voluntary shared job (two } \\
\text { employees working half time) }\end{array}$ & $20.60 \%$ & $28.14 \%$ & $18.59 \%$ & $9.55 \%$ & $23.12 \%$ \\
\hline $\begin{array}{l}\text { Possibility to telework full } \\
\text { time }\end{array}$ & $14.29 \%$ & $13.78 \%$ & $23.47 \%$ & $14.29 \%$ & $34.18 \%$ \\
\hline
\end{tabular}




\section{Appendix C: Measures or Incentives to Stay in Employment Longer According to Professional Category}

\begin{tabular}{|c|c|c|c|c|c|}
\hline Additional leaves & Very interesting & interesting & Neutral & $\begin{array}{l}\text { Not really } \\
\text { interesting }\end{array}$ & $\begin{array}{c}\text { Not } \\
\text { interesting } \\
\text { at all }\end{array}$ \\
\hline Manufacturing workers & $23 \%$ & $23 \%$ & $23 \%$ & $15 \%$ & $15 \%$ \\
\hline Public sector & $24 \%$ & $30 \%$ & $11 \%$ & $13 \%$ & $21 \%$ \\
\hline Education / Research & $13 \%$ & $4 \%$ & $32 \%$ & $9 \%$ & $41 \%$ \\
\hline Finances, insurance, real estate & $36 \%$ & $21 \%$ & $43 \%$ & 0 & 0 \\
\hline Health sector & $44 \%$ & $44 \%$ & $9 \%$ & 0 & $3 \%$ \\
\hline Longer annual holiday & Very interesting & Interesting & Neutral & $\begin{array}{l}\text { Not really } \\
\text { interesting }\end{array}$ & $\begin{array}{c}\text { Not } \\
\text { interesting } \\
\text { at all }\end{array}$ \\
\hline Manufacturing workers & $31 \%$ & $31 \%$ & $8 \%$ & $22 \%$ & $8 \%$ \\
\hline Public sector & $40 \%$ & $20 \%$ & $17 \%$ & $7 \%$ & $15 \%$ \\
\hline Education / Research & $12 \%$ & $17 \%$ & $21 \%$ & $12 \%$ & $37 \%$ \\
\hline Finances, insurance, real estate & $40 \%$ & $40 \%$ & $20 \%$ & 0 & 0 \\
\hline Health sector & $62 \%$ & $28 \%$ & $6 \%$ & 0 & $3 \%$ \\
\hline $\begin{array}{l}\text { Possibility to telework some } \\
\text { days a week }\end{array}$ & Very interesting & Interesting & Neutral & $\begin{array}{l}\text { Not really } \\
\text { interesting }\end{array}$ & $\begin{array}{c}\text { Not } \\
\text { interesting } \\
\text { at all }\end{array}$ \\
\hline Manufacturing workers & $31 \%$ & $31 \%$ & $7 \%$ & 0 & $31 \%$ \\
\hline Public sector & $29 \%$ & $20 \%$ & $20 \%$ & $20 \%$ & $11 \%$ \\
\hline Education / Research & $33 \%$ & $7 \%$ & $20 \%$ & $7 \%$ & $33 \%$ \\
\hline Finances, insurance, real estate & $20 \%$ & $28 \%$ & $14 \%$ & $7 \%$ & $30 \%$ \\
\hline Health sector & $21 \%$ & $14 \%$ & $17 \%$ & 0 & $48 \%$ \\
\hline
\end{tabular}




\section{Appendix D: Rotated Matrix of Principal Component Analysis}

\section{Rotated principal components matrix}

\begin{tabular}{l|c|c|c}
\hline & \multicolumn{2}{|c}{ Component } \\
\cline { 2 - 4 } & 1 & 2 & 3 \\
\hline Reduced week in 4 days (paid 4 days) & & .549 & \\
Constricted week in 4 days (paid the total of the normal & & .567 & \\
hours) & & .559 & \\
Shorter working days & & .799 & \\
Additional leaves & & .798 & \\
Longer annual holiday & & .459 \\
Flexitime & & .890 \\
Possibility to telework full time & & .872 \\
Possibility to telework some days a week & & \\
\hline Flexible working hours at the end of career & .506 & & \\
Voluntary shared job (two employees working half time) & .485 & & \\
Voluntary reduced working time & .648 & & \\
Progressive retirement & .654 & & \\
Retirement and part-time job in the same organization & .805 & & \\
Retirement and activity or job in another organization & .673 & & \\
\hline
\end{tabular}

Extraction method: principal component analysis

Rotation method: Varimax with Kaiser normalization. The rotation led to 7 iterations. 